


\title{
UNIVERSITY BUSINESS EDUCATION IN SOUTHERN AFRICA: A ZAMBIAN FOCUS
}

\author{
Nessan J. Ronan \\ The Copperbelt University \\ Kitwe, Zambia
}

\section{Abstract}

There is widespread concern with the quality of university business education in Southern Africa. Universities are confronted with lowering academic standards, staff attrition, and dwindling financial resources. In this paper, these issues are addressed in the context of university education in Zambia. The central issues are analysed and recommendations are made for improvements.

\section{Introduction}

Concern about the quality of higher education in Southern Africa, is regularly expressed by both citizens and international donors. Behind the concerns expressed are issues about how a country can compete economically in the global marketplace. Because everyone is aware that today, countries compete on their competencies. Thus, a well-educated population is the best guarantee for future economic development. But is the concern with quality overplayed and exaggerated? This paper attempts to answer this question drawing on the literature and the author's experience as a lecturer and examiner in the region with special reference to Business Education. It begins by pointing to the changing job scene and the new rules of competition. The paper then goes on to review the funding of education both in Zambia and selected countries in Southern Africa. This is followed by some recommendations on improving higher education in Southern Africa. While this paper focuses on Southern Africa, the Zambian perspective is the one adopted in making comparisons.

\section{The Changing Job Scene}

Over the past decade a number of writers have been sounding warnings on the changing global economic environment. We are witnessing a change in the structure of business and trade whereby the global imperatives have a significant influence. Thus, firms in Africa are now subject to much more competition and less protection for home industries. This has resulted in a significant 
number of local businesses being unable to compete effectively. The upheaval in business competition hàs brought about a number of phenomena including delayering, downsizing, and retrenchment.

Internationally, the concept of the job as we know it is undergoing a fundamental revision. No longer can anyone expect guaranteed lifetime employment and employees are being encouraged to take more responsibility for the management of their careers. They are also being encouraged to provide their services not as employees but as independent contractors. Handy (1995) terms these "portfolio people".

These are the people who provide services to companies but any one company does not employ them. They act like consultants except that they are providing routine services. Bridges (1995) warns that in future all workers will have a hard time finding security in a job. He encourages employees to think like vendors and to ensure that they have something relevant to sell. He also suggests that all opportunities should be seen in terms of markets. Further evidence for the change in jobs comes from Herriot and Pemberton (1995) who perceive that the psychological contract of employment is undergoing a radical change. No longer can an employee count on loyalty and competence to keep his job. Even the competent to day can be declared redundant. It has little to do with competence and everything to do with markets.

\section{Competing in the Global Arena}

The advent of the Japanese challenge to the Western dominance of business in the 1970s has encouraged intensive research in to competitiveness. Both Europe and the United States have led a sustained search for the key determinants of competitiveness. A seminal article by Hayes and Abernathy (1980) drew attention to the loss of competitiveness by American industry. They attributed these economic problems to the dysfunctional culture of American organisations. An influential book by Athos and pascale (1981) compared American and Japanese industry and drew unfavourable conclusions about American work practices. The debate continued with a groundbreaking report onAmerican industry by Peters and Waternan (1982) who reviewed the performance of a selection of American companies. They claimed that successful companies possessed, among other things, a strong culture. On the other side of the Atlantic Goldsmith and Glutterback (1984) published a book in Britain purporting to show how British companies could compete favourably in the global business arena. 
Figure 1 depicts how quality education can contribute to the achievement of competitive advantage.

Figure 1: A Model of Successful Economic Societies

\begin{tabular}{|lll|}
\hline Output & Process & Input \\
\hline Competitive & Competence & Quality \\
Advantage & Development & Education \\
\hline
\end{tabular}

Michael Porter (1990) offers us a model of Competitive Advantage of nations and specifies the necessary conditions for success. He claims that for any nation to be able to develop and sustain a competitive advantage, it must possess, inter alia, a set of favourable factors of production. These factors include human resources, knowledge, and financial resources. While acknowledging that a skilled workforce is not a sufficient condition for securing a competitive advantage it most definitely is one of the essential components. The modern approach to human factor enhancement is through competency development. McClelland (1973) was one of the first researchers to draw attention to the importance of the competency approach to skills development. Since then the competency approach has taken on the characteristics of a new paradigm. In the context of business organisations a number of writers (Boyatzis, 1982, Spencer and Spencer 1993, Cox and Copper, 1988) have developed competency clusters for a wide range of managerial functions.

Competency development is facilitated through the learning organisation (Senge 1990, Garratt, 1987) operating through the culture of the lifelong learner. Thus we can see the importance of promoting and sustaining lifelong learners if a country is to achieve and sustain a competitive advantage.

\section{Zambia in Context}

Zambia gained independence from Britain in 1964 and constituted itself as a republican democracy with an elected president. Its population is about 10 million made up of about70 African ethnic groups. Its natural resources include agriculture and mining with copper production being the main foreign exchange earner. Since 1991, with the election of the MMD (multi-party democracy) government, the country has embarked on an ambitious programme of privatisation and liberalisation. 
Table 1 contains some statistics on Zambia in relation to its human development. Zambia has a human development index of 143, which compares to 97 for Botswana and 118 for Namibia while Zimbabwe has a rank of 129. Thus, Zambia compares unfavourably with its near neighbours on its human development.

\section{Table 1 : Human Development Statistics on Zambia}

Lifé expectancy

Adult literacy rate

Primary \& secondary enrolment

GDP per capita (PPP\$)

Human development index
42.6 years

$76.6 \%$

$48 \%$

962

143

Source: Human development report 1997, UNDP, New York

The populace's average life expectancy is very low at 42 years and is likely to go even lower with the AIDS pandemic. The percentage of the age cohort enrolled in primary and secondary education is less than $50 \%$. Table 2 contains comparative data on the amount of government expenditure on education.

Table 2 : Public Expenditure on Education as a \%age of GNP

\begin{tabular}{lcc}
\hline. & 1980 & 1994 \\
\hline Botswana & 7.0 & 8.5 \\
Namibia & 1.5 & 8.7 \\
Zimbabwe & 6.6 & 8.3 \\
Zambia & 4.5 & 2.6 \\
\hline
\end{tabular}

Source: Human development report 1997, UNDP, New York

The picture emerging for Zambia is that its expenditure on education as a percentage of GNP declined from 1980 at 4.5 to $2.6 \%$ in 1994 . This is an extremely poor performance especially in relation to its neighbours with whom it has to compete. Botswana, Namibia, and Zimbabwe all managed to raise the amount spent on education during this period. The Zambian performance indicates that the government gives a low priority to education in terms of budgetary allocation. When we proceed to examine the government allocations in terms of total government expenditure, the position for Zambia is even worse. 
Table 3: Expenditure on Education as a \%age of their State Budget

\begin{tabular}{lllll}
\hline Botswana & 19.3 & 17.6 & 17.5 & 18.7 \\
Swaziland & 18.3 & 17.5 & 20.6 & 23.0 \\
South Africa & 21.6 & 22.9 & 22.1 & $n / a$ \\
Zambia & 6.5 & 9.2 & 7.7 & 7.1 \\
\hline
\end{tabular}

Source: UNESCO, Education Statistics, Internet Database

Clearly, Zambia's expenditure on education as a percentage of its total government budget has not changed significantly over the four years under consideration. This policy of neglect contrasts sharply with that of South Africa, Botswana, and Swaziland who have made enormous strides in developing an enabling environment for education to flourish. South Africa's government expenditure on education represents three times that of Zambia. It should not be surprising if countries like South Africa perform much better in socio-economic terms than Zambia.

We can fairly conclude from the data presented that successive Zambian governments have given a low priority to expenditure on education and do not consider investment in education to play any significant role in gaining a competitive advantage for the nation. When we focus on the financing of university education in Zambia the scenario will also reflect a culture of neglect and apathy by government. But before we consider the White Paper on university education we will briefly review the position on financing higher education in Sub-Saharan Africa.

\section{Financing Higher Education}

The financing of higher education is an area of debate all over the world. In Africa, it has become a major problem for governments because of severely constrained financial budgets coupled with (urgent) competing demands. In the past decade a number of major reports dealing with this issue have been presented. The World Bank (1988) makes a cogent case for restructuring educational financing;

"Public Ownership and control of higher education in Africa has meant for all practical purposes that tertiary education-including the living costs of its students which are not properly an educational expense - is entirely financed by the Public Budget". (World Bank 1988, p.77). 
The Bank advocates, inter alia, an expanded scheme of cost sharing by beneficiaries. A later Bank Report (World Bank, 1993) states that higher education in both the developed and developing world is in crisis due to an over dependence on government funding coupled with high unit costs. An ODA (1984) report on education in sub-Saharan Africa draws attention to the problems created by high costs per student in the higher levels of education.

The crisis in higher education in sub-Saharan Africa is exacerbated by a rather poor record of policy implementation (Craig, 1990) and relatively little progress by universities in diversifying their sources of finances (Saint, 1992).

\section{Higher.Education Standards}

Higher education has in the last quarter century been confronted with significant and threatening challenges. The role of universities in the modern world continues to be challenged and questioned. Hills (1994) views the role of the modern university to train people to manage and gain access to the universal database of knowledge. The main challenge facing African universities is seen by Sherman (1990) as integrating African culture with the modern world. The World Bank (1988) believes that the main challenges facing university education in Sub-Saharan Africa are how to cope with declining quality and standards.

There is no shortage of proposals to deal with the crisis in higher education. Posnansky (1989) recommends that African universities should expand technological and commercial training to provide middle management skills. Other suggestions include fostering modest but persistent educational devel oment (Miller, 1987), fewer but better students (Malikamkono, 1991) and a better. latch between educational output and human resources needs of the economy $(\mathrm{Na}-$ tional Commission on Education, 1993).

In all cases the suggestions encompass a need for change, reflecting as they do a reaction to the recent phenomenon of graduate unemployment in both developed and developing countries. Advocates of change point to the need for tertiary educational institutions to respond positively to societal demands for greater relevance in educational offerings. Relevance in this context implies that graduates should be easily absorbed into the labour market. Thus, they should be equipped with the relevant skills and competencies required by the labour market.

It has been contended, that the most effective universities in the next few 
decades, will be those able to adapt to a changing workforce and shifting demands of business (Dodson, 1993) while Zensky and Odel believe that the biggest challenge facing higher education today is to meet degree programmes which provide genuine job skills. Clark (1993) argues that institutions of higher education must indulge in strategies such as benchmarking in order to further develop instructional paradigms. It has been found that educational innovation tends to go hand in hand with organisational development (Van Meel, 1993).

\section{University Education in Zambia}

In 1997 a presidential enquiry into the functioning of the two universities in Zambia (University of Zambia and the Copperbelt University) was established. It was chaired by Justice Bwalya with wide terms of reference. On the basis of the report of this commission the government issued a White Paper containing the recommendations of the "Bwalya Commission" and its reaction to the various proposals. The White paper runs over 100 pages and provides a wealth of useful information and statistics on the functioning of the universities.

Participating in lifelong learning requires an enabling environment whereby all who desire or need access to continuing education are facilitated. This enabling environment requires that institutions of higher education have the necessary resources to provide a learning environment, which encourages participation. Given this context the White Paper will be reviewed from the perspective of the assistance rendered by Government to the two universities and the resultant capabilities developed.

\section{Financing the two Universities}

The White Paper contains data on the total financing for the two universities from 1993 to 1996 inclusive. The data has been adjusted for inflation by converting the $\mathrm{K}$ wacha values into United State dollars. The resultant figures are in Table 4. 
Table 4 : Financing the Zambian Universities (US\$)

\begin{tabular}{lrl} 
& \multicolumn{1}{c}{ UNZA } & CBU \\
\hline 1993 & $6,617,000$ & $2,273,000$ \\
1994 & $12,134,000$ & $4,046,000$ \\
1995 & $15,493,000$ & $3,948,000$ \\
1996 & $8,771,000$ & $2,880,000$ \\
\hline
\end{tabular}

Key: UNZA $=$ University of Zambla CBU $\approx$ Copperbelt University

Source: White Paper on University Education 1998

The University of Zambia financing shows a pattern of wide fluctuation over the four years. In 1994 and 1995 there was a substantial increase in financing but in 1996 there was a significant decline. This decline in funding appears to have carried over to the present. It can be attributed partly to the financial mismanagement at that university as reported by the commission.

The Copperbelt University has experienced a similar pattern of funding to that of the other university. We will see later that the under financing of both universities has led to a deterioration in teaching, research, and library resources.

\section{Teaching Resources}

The White paper acknowledges that the "universities are understaffed in the critical areas which are central to their function". Table 5 quantifies the understaffing in terms of established posts filled.

Table 5: Academic Staffing at the two UNZA and CBU

\begin{tabular}{lllll}
\hline & \multicolumn{3}{c}{ UNZA } & \multicolumn{2}{c}{ CBU } \\
\hline & POSTS & Filled & Posts & Filled \\
Professor & 106 & 54 & 21 & 3 \\
Lecturer & 540 & 416 & 218 & 135 \\
\hline Irainee lecturers & 42 & 17 & 6 & 3 \\
\hline UNZA = University of Zambia & CBU = Copperbelt University
\end{tabular}

Source: White Paper on University Education 1998 
The teaching resources available at both universities indicate over $50 \%$ of vacant posts at the professorial level. At the lecturer level the position is a little better but still totally inadequate. A worrying feature is the relatively small number of trainee lecturers in the system. Clearly, it is unrealistic to expect much by way of academic development from institutions with such inadequate academic staffing. Unless the universities can radically improve the academic staffing, there will be an inevitable decline in the quality and quantity of university education in Zambia. The poor academic staffing is attributable in the main to the poor salaries offered. The White paper acknowledges this position and recommends that the salaries be raised to comparable levels in the region. The Government's response to this recommendation has been ambiguous, in that it accepts the principle of regional parity in salaries, but does not commit itself to implementation.

This is another manifestation of the priorities of Government.

The White Paper draws attention to the limited resources allocated to university libraries and blames university management for this position. It also refers to the low research and publication output by both universities. This of course is a reflection of the poor salaries, which forces academic staff to engage in non-academic work to supplement their salaries. The White Paper urges the universities to develop closer linkages with the business community to be able to render significant financial assistance to the universities. The business community in Zambia is itself facing tremendous challenges from a liberalised economy, which has experienced hyperinflation since 1991.

\section{Recommendations}

The financing situation described above for Zambia is applicable to the whole region but to different degrees. The following recommendations are made, with the purpose of improving higher education. They are based on three assumptions:

(1) Government is unable to fund higher education to the extent that is required.

(2) It is in everyone's interest to maintain adequate educational standards

(3) Business graduates can look forward to attractive career opportuni ties with enhanced salaries. 


\section{Set Economic and Differential Fees}

Government should permit universities to set economic and differential fees, reflecting their internal costs and the realities of the marketplace. Higher education should no longer be treated as a social welfare commodity, which has to be highly subsidised by government.

\section{Establish a Bursary System}

Government should establish a bursary system, which is available to the following applicants:

(a) Those who are considered, through the administration of a means test be unable to pay the fees and other costs.

(b) While lacking the financial means, have a good academic record as evidenced by the school examinations.

\section{Reduce Staffing Levels}

Universities should reduce their staffing levels and increase their salaries. In this way, it may be possible to motivate the staff retained.

\section{Evaluate Teaching Performance}

Universities should put in place a system for the evaluation of the teaching performance of academic staff. This initiative would assist in identifying those who are not performing up to standard. There are very few universities in the region with a teaching assessment system in operation.

\section{Benchmark.Academic Standards}

The Southern African Development Community Education Ministers should establish and fund a system for benchmarking the academic standards of universities in the region. It should then be possible to produce a ranking system, which would provide an incentive for continuous improvements

\section{Conclusions}

The advent of the global village with its competitive imperatives demands that all nations focus their resources on gaining competitive advantage through the development of competencies. These competencies are by their nature changing, requiring a determination to maintain a quality education system. 
We normally look to our universities as the catalysts for quality educational standards. The position on university education in Zambia is very disappointing with a system, which is grossly under sourced. This level of resourcing government is reflected throughout the system. Funding of education in Zambia compares unfavourably with its neighbouring countries. Bold and radical strategies are required by Government and other stakeholders to correct this malaise. Failure to come to terms with this problem will inevitably lead to a situation where Zambia will not have the required skilled manpower to compete in international markets. The Government's proposal to establish an Open University is a step in the right direction. But an Open University should not be seen primarily as an opportunity to save on educational spending. Above all, what is required is amore focused government strategy, which sees economic development in the context of a number of crucial variables including manpower development.

\section{References}

Athos, A.G. \& Pascale, R.T. (1981). The art of Japanese management. New York: Simon \& Schuter.

Boyatzis, R.E. (1982). The competent manager. New York: Wiley.

Bridges, W. (1995). Jobshift: How to prosper in a workplace without jobs. London: Nicholas Braeley.

Clark, K.I. (1993). Benchmarking as a global strategy for improving instruction in higher education. Paper presented at $11^{\text {th }}$ Conference on New Concepts in Higher Education, Phoenix, December, 5-9.

Cox, C.J. \& C.L. Cooper (1988). Higher flyers: An anatomy of managerial success. Oxford: Basil Blackwell.

Craig, J. (1990). Comparative African experiences in implementing educational policies. Washington: World Bank.

Dodson, J. (1993). The changing workforce: Human resources challenges. Business Offer, 26(12), 32-35.

Garratt, R. (1987). The learning organisation. Aldershot: Gower.

Goldsmith, W. \& Clutterback, D. (1984). The winning streak. London: Weidenfeld. 
Handy, C. (1995). Beyond certainty: The changing worlds of organisations. London: Hutchinson.

Hayes, R.H. \& Abernathy, W.J. (1980, July August). Managing our way to economic decline. Harvard Business Review.

Harriot, P. \& Pemberton, C. (1995). New Deals: The revolution in managerial careers. Chichester: John Wiley.

Hills, G (1994). Universities of tomorrow. CEPES papers on higher education, European Centre for Higher Education, Bucharest.

Johns Philip, W. (1992). World Bank financing of education. London: Routledge.

Maliyamkono, T.L. (1989). Higher education in Eastern and Southern Africa. Prospects, 21 (3), 351-362.

Miller, R.M. (1989). The fading future. Comparative Education Review, 31 (2) $1,216-240$.

McClelland, D.C. (1973). Testing for competence rather than for intelligence. American Psychologist, 28, 1-14.

Overseas Development Administration (1984). Education priorities and aid responses in sub-Saharan Africa. London: ODA.

Peters, T.J. \& Waterman R.H. (1982, November). In search of excellence. New York: Harper \& Row.

Posansky, M. (1989). Restructuring the African university: A case study from Ghana. Paper presented at the Annual Conference of African Studies Association, Atlanta.

Republic of Zambia. (1998). Government paper no. 1 of 1998. Summary of the main findings and recommendations of the commission of inquiry into the operations of the University of Zambia and Copperbelt University and Government reaction to the report.

Republic of Botswana. (1993). Report of the National Commission on Education. Gaborone: Government Printer.

Saint William, S. (1992). Universities in Africa: Strategies for stabilisation and revitalisatioṇ. Washington: World Bank. 
Zimbabwe Journal of Educational Research

Sage, P.M. (1990). The fifth discipline. London: Century Books.

Sherman, M.A.B. (1990). The university in modern Africa: Towards the twenty first century. Journal of Higher Education, 61 (4), 363-385.

UNESCO. Education statistics. www.eduaction.unesco.org.

United Nations Development Programme (1997). Human development report. New York: UNDP.

Van Miel, R.M. (1993). Modernisation and Flexibilisation Centre for Educational Technological Innovation, Herleen, Netherlands, Open University.

World Bank. (1988). Education in Sub-Saharan Africa: A World Bank policy study. Washington: World Bank.

World Bank. (1993). Higher education: The lessons of experience. Washington: World Bank.

Zensky, R \& Odel, P. (1994). Higher education and the changing nature of the American workforce: Responses, challenges and opportunities. National Centre on Educational Quality of the workforce. Philadelphia. 


\section{(c) (1) (9)}

This work is licensed under a

Creative Commons

Attribution - NonCommercial - NoDerivs 3.0 License.

To view a copy of the license please see:

http://creativecommons.ora/licenses/bv-nc-nd/3.0/ 